\title{
Study of the composition of seminal fluid and of sperm motility along the genital tract, during a spawning season, in the rainbow trout (Oncorhynchus mykiss)
}

\author{
Malgorzata Koldras (1), Maurice L_oir (2)*, \\ Gérard Maisse ${ }^{(2)}$ and Florence Le Gac ${ }^{(2)}$ \\ (1) Inland Fisheries Insilule, 32-640, Zator, Poland. \\ (2) INRA, Physiologie des Poissons, 35042 Rennes Cedex, France. \\ * Address for correspondence: M. I,oir, E-mail: ml@rennes.inra.fr.
}

Received July 3, 1996; accepted September 17, 1996.

Abstract

Résumé

Koldras M., M. Loir, G. Maisse, F. Le Gac, Aquat. Living Resour, 1996, 9, 337-345.

Sperm was collected from testes and from three or four parts of the deferent ducts of 4 to 6 winter-spawning male rainbow trout, about every two weeks over a three month period (January to March). Milt volume, spermatocrit, sperm motility, 11-ketotestosterone (11-KT) and 17 $\alpha$-hydroxy,20 $\beta$ dihydroprogesterone (17,20P) levels and ionic composition were determined. Steroids and ions were also measured in blood plasma. The $\mathrm{K}^{+}$concentrations and steroid levels in the seminal fluid from each part of the ducts did not vary significantly over the period of study. In two out of the three parts of the ducts, $\mathrm{Na}^{+}$(parts I and III) $\mathrm{Ca}^{2+}$ (parts I and III) and $\mathrm{Mg}^{2+}$ (parts I and II) levels were significantly higher at the end of March than two months earlier. Motility of testicular sperm peaked (42\%) in mid-February while that of sperm from ducts usually remained stable $(80)$ to $100 \%)$ throughout the three months.

Seminal fluids and blood plasma were confirmed to be isotonic $(300 \mathrm{mmol} / \mathrm{kg})$. Levels of $\mathrm{K}^{+}, \mathrm{Na}^{+}, \mathrm{Ca}^{2+}$, I1-KT and 17,20P in the plasma and seminal fluid differed significantly (respectively $0.3 \mathrm{vs} 34 \mathrm{mmol}$, 134 vs $116 \mathrm{mmol}, 3.4$ vs $2.0 \mathrm{mmol}, 87$ vs 17 to $39 \mathrm{ng} / \mathrm{ml}, 11 \mathrm{vs} 3$ to $13 \mathrm{ng} / \mathrm{ml}$ ), with the $\mathrm{Na}^{+}$and steroid levels being positively correlated in both liquids. Osmolality, $\mathrm{Cl}^{-}, \mathrm{Na}^{+}, \mathrm{K}^{+}, \mathrm{Mg}^{2+}$ and $\mathrm{Ca}^{2+}$ concentrations remained constant along the genital tract. In contrast, spermatocrit and 11-KT and 17,20P levels decreased significantly and progressively from testis to the posterior or middle part of the ducts (respectively 97 to $49 \%, 39$ to $17 \mathrm{ng} / \mathrm{ml}, 13$ to $3 \mathrm{ng} / \mathrm{ml}$ ) while sperm motility (percentage of motile cells and duration of motility) increased ( 74 to $96 \%$ and 41 to $51 \mathrm{~s}$ ). No significant correlation was found between sperm motility and the studied physicochemical parameters of the seminal fluid.

Keywords: Trout, sperm motility, seminal fluid, hormones, ions, steroids.

Etude de la composition du fuide séminal et de la motilité des spermatozoïdes dans le tractus génital de la truite arc-en-ciel (Oncorhynchus mykiss), au cours d'une période de reproduction.

Le sperme testiculaire et celui contenu dans les canaux déférents, divisés en trois ou quatre parties, ont été collectés sur 4 à 6 mâles de truite arc-en-ciel de souche hivernale, environ toutes les deux semaines pendant trois mois (Janvier à Mars). Le volume de sperme, le spermatocrite, la motilité des spermatozoïdes, les concentrations en 11 -ketotestosterone $(11-\mathrm{KT})$ et en $17 \alpha$-hydroxy,20 $\beta$-dihydroprogesterone $(17,20 \mathrm{P})$, ainsi que la composition ionique, ont été déterminés. Les deux stéroïdes et les ions ont aussi été mesurés dans le plasma sanguin. Les concentrations en $\mathrm{K}^{+}$et en stéroïdes dans le fluide séminal de chacune des parties des canaux déférents n'ont pas varié significativement pendant la période étudiée. Dans deux parties sur trois des canaux déférents, les concentrations en $\mathrm{Na}^{+}$(parties I et III), en $\mathrm{Ca}^{2+}$ (parties I et III) et en $\mathrm{Mg}^{2+}$ (parties I et II) étaient significativement plus élevées à la fin Mars que deux mois plus tôt. La motilité des spermatozoïdes testiculaires était maximale $(42 \%)$ à la mi-Février, tandis que celle des spermatozoïdes des canaux déférents restait stable pendant les trois mois (80 à $100 \%$ ). 
Il a été confirmé que le fluide séminal et le plasma sanguin sont isotoniques $(300 \mathrm{mmol} / \mathrm{kg})$. Les concentrations en $\mathrm{K}^{+}, \mathrm{Na}^{+}, \mathrm{Ca}^{2+}, 11-\mathrm{KT}$ et $17,20 \mathrm{P}$ dans le plasma sanguin et le fluide séminal différaient significativement (respectivement 0,3 et $34 \mathrm{mmol}, 134$ et $116 \mathrm{mmol}, 3,4$ et 2,0 mmol, 87 et 17 à $39 \mathrm{ng} / \mathrm{ml}$, 11 et 3 a $13 \mathrm{ng} / \mathrm{ml}$ ). Les concentrations en $\mathrm{Na}^{+}$et en stéroïdes dans les deux milicux ćtaicnt corrélécs. L'osmolarité et les concentrations en $\mathrm{Cl}, \mathrm{Na}^{+}, \mathrm{K}^{+}, \mathrm{Mg}^{2+}$ and $\mathrm{Ca}^{2+}$ restaient constantes tout au long du tractus génital. Par contre, le spermatocrite et les concentration en 11-KT el en 17,20P diminuaient progressivement des testicules à la partic postćricure des canaux (respectivement 97 à $49 \%, 39$ à $17 \mathrm{ng} / \mathrm{m}$ ), 13 à $3 \mathrm{ng} / \mathrm{ml}$ ), alors que la motilité des spermatozoïdes (pourcentage de cellules mobiles et durée de la motilité) augmentait $(74$ à $96 \%$ ct 41 à 51 s). Il n’a pas ćté trouvé de corrélation significative entre la motilité des spermatozö̈des et les paramètres physicochimiques du fluide séminal.

Mots-clés : Truite, spermatozüides, motilité, fluide séminal, hormones, ions, stérnïdes.

\section{INTRODUCTION}

Some studies have provided information about the osmolality, ionic composition and steroid concentrations of seminal fluid from ejaculated milt in salmonid fish, some of them comparing this with blond plasma (Morisawa et al., 1983; Morisawa, 1985; Piironen, 1985; Munkittrick and Moccia, 1987; Malejac et al., 1990; Loir et al., 1990; Lahnsteiner et al., 1992). Seminal fluid is mainly characterized by a far higher $\mathrm{K}^{+}$concentration than that of blood plasma, which is responsible for the suppression of sperm motility (Billard, 1975; Benau and Terner, 1980; Morisawa et al. 1983; Morisawa, 1985). Steroids may be involved in the control of the ionic composition of the seminal fluid and of the volume of milt (Baynes and Scott 1985; Marshall and Bryson, 1988; Marshall et al., 1989).

Contradictory reports occur concerning the evolution of the physicochemical parameters of salmonid milt throughout the breeding season, the differences perhaps reflecting interspecies or interstrain variations. While the fertility of sperm from a spring-spawning trout strain does not decrease at the end of the breeding season (Maisse et al., 1988), it decreases for a winter-spawning strain (Billard, 1976). As the breeding season progresses, spermatocrit, motility, seminal plasma ion concentrations (Munkittrick and Moccia, 1987), ATP and CAMP levels (Benau and Terner, 1980) decline in the trout, while in the Finnish landlocked salmon, some of these parameters either increase continuously or show specific changes (Piironen, 1985).

Very little information has been published that describes the changes which occur along the salmonid genital tract, for various physicochemical parameters of milt (Morisawa and Morisawa, 1986; Billard and Cosson, 1992; Morisawa et al., 1993; Loir et al., 1990). For one trout strain, intratesticular sperm are active in fertilization, but sperm from the deferent duct are significantly more active (Bi]lard, 1976). When the motility of testicular trout spermatozoa is checked after dilution of $\mathrm{K}^{+}$in the presence of a low concentration of $\mathrm{Ca}^{2+}$, the motility and the pattern of flagellar movement of these sperm are comparable to those of sperm in the semen (Billard and Cosson, 1992). However, the motility of testicular spermatozoa is close to zero when checked in the absence of $\mathrm{Ca}^{2+}$ (Miura et al., 1992; Maisse et al., 1995). The gametes then acquire the potential for motility during the transition from the testis to the sperm duct as a consequence of increases of seminal fluid bicarbonate concentration and of $17 x$ hydroxy,20/3-dihydroprogesterone $(17,20 \mathrm{P})$ which is mediated through an increase in sperm duct $\mathrm{pH}$ (Morisawa and Morisawa, 1986, 1988; Miura et al., 1992; Morisawa et al., 1993). These observations indicate the importance of divalent cations and the possible role of steroids in the control of sperm motility. In mammals, steroids have been shown to modify $\mathrm{Ca}^{2+}$ exchange across the spermatozoan membrane and induce ultimate maturational events in the gametes (Meizel and Turner, 1991; Blackmore et al., 199()).

The present study has been undertaken in order to addlress the following two questions: which physicochemical and biological milt parameters vary throughout the breeding season and which parameters undergo changes along the trout genital tract? Is there any relationship between these changes and the maturation and/or ageing of sperm, as estimated by sperm motility? Such knowledge would be useful for fish farming management and especially for handling and storage of salmonid sperm.

\section{MATERIALS AND METHODS}

\section{Fish and collection of milt samples from the genital tract}

The experiments were carried out on male rainbow trout at the INRA experimental fish farm, in Drennec (Brittany).

\section{Experiment 1}

A total of 28 spermiating winter-spawning males were used. They were 3 years old (average weight $2.9 \mathrm{~kg}$ ) and sexually mature for the first time. They were kept in freshwater tanks under natural photoperiod, without any feeding during the experiment. Water temperature varied from 5.5 (January) to $8.5^{\circ} \mathrm{C}$ 
(March). Water mineral composition was $0.43 \mathrm{mmol}$ $\mathrm{Na}^{+}, 0.03 \mathrm{mmol} \mathrm{K} \mathrm{K}^{+}, 0.12 \mathrm{mmol} \mathrm{Ca}^{2+}, 0.12 \mathrm{mmol}$ $\mathrm{Mg}^{2+}$ and $0.6 \mathrm{mmol} \mathrm{Cl}^{-}$.

Groups of 6 fish were randomly sampled on each of the following dates: January 7 th and 22th, February 10 th and 24th and a group of 4 fish was sampled on March 24th. This sampling period corresponds to the middle of the spermiation period. Fish were anaesthetized with $0.03 \%$ phenoxyethanol. Blood was taken from the caudal vein before sacrifice, in the presence of heparin $\left(\mathrm{Na}^{+}\right.$and $\mathrm{K}^{+}$free), for ionic assays, together with 11-ketotestosterone (11-KT) and $17 \alpha$-hydroxy, 20 $\beta$-dihydroprogesterone $(17,20 \mathrm{P})$ assays. Blood plasma was collected after centrifugation at $3000 \mathrm{~g}$ for $15 \mathrm{~min}$, then frozen at $-20^{\circ} \mathrm{C}$ until use. After the fish were killed, milt was collected from the deferent ducts and testes (right and left separately) in the following way. Each deferent duct was clamped at about an equal distance between the posterior end of the testis and the genital papilla and again at the level of the posterior cnd of the testis. The two clamps determined three deferent parts: postcrior (III), middle (II) and antcrior (I; juxtatesticular portion of the deferent duct). Milt was removed from each part by means of a syringe fitted with a needle. Testes were then removed, cut in small pieces, and pressed through a $150 \mu \mathrm{m}$ nylon mesh to expel whole testicular milt (G). The volume of the milt samples (usually 8 per fish) was measured and expressed per $1 \mathrm{~kg}$ of total body weight. Sperm motility was estimated in each part of the ducts and in both testes. Milt samples were then centrifuged at $500 \mathrm{~g}$ for $20 \mathrm{~min}$ and afterwards at $1000 \mathrm{~g}$ for $10 \mathrm{~min}$. Spermatocrit ("spermatocrit 1000 g") was measured from the ratio of pellet to total milt volume. In the case of $\mathrm{G}$ samples, because of the high spermatocrit, the tubes were centrifuged again at $1500 \mathrm{~g}$ for another $30 \mathrm{~min}$ to allow collection of some testicular fluid. No testicular fluid could be collected in January. The supernatants ("seminal fluid") were then collected and frozen.

\section{Experiment 2}

Nine spermiating autumn-spawning males were used on December 3rd. They were gently anaesthetized in the tanks, without being netted, with $0.018 \%$ phenoxyethanol. Blood was collected and plasma processed as indicated above. Milt was collected from deferent ducts and testes as above, with the following modification. The anterior juxtatesticular part of each duct was divided in 2 equal parts with a third clamp. Thus, every duct was divided into 4 parts (I, II, III, IV). "Spermatocrit $1000 \mathrm{~g}$ " was measured. The tubes were then centrifuged again at $3000 \mathrm{~g}$ for $10 \mathrm{~min}$ and the supernatants were collected and frozen. The osmolality and the concentrations of $11-\mathrm{KT}$ and $17,20 \mathrm{P}$ were assayed in every blood plasma and seminal fluid sample.

\section{Sperm motility}

Sperm motility was determined by subjective estimates of percentage of motile sperm cells and by the duration of motility (length of time before most cells became immotile; Billard and Cosson, 1992) according to Billard and Cosson (1992; 100 fold dilution then 20 fold dilution directly on the microscope slide; light microscope, magnification $\times 160$ ). Motility was tested in diluent for artificial insemination (DIA 532: $100 \mathrm{mmol} \mathrm{NaCl}$, $50 \mathrm{mmol}$ glycinc, 20 mmol Tris; Billard, 1977) and in 4 solutions containing $0,5,10$ and $20 \mathrm{mmol} \mathrm{KCl}$ plus respectively $120,115,110$ and $100 \mathrm{mmol} \mathrm{NaCl}$. $\mathrm{pH}$ of the above 5 solutions was adjusted to 9.0 and osmolality was equal to $250 \mathrm{mmol} / \mathrm{kg}$.

\section{Osmolality and ion measurements}

The osmolality of blood and seminal fluids was measured with a vapour pressure osmometer (Wescor 5000). The concentrations of sodium, potassium, calcium and magnesium were determined using an atomic absorption spectrophotometer (Varian AA1275). Fifty to $100 \mu$ l samples were appropriately diluted to fit in the range $0.5-2.0 \mathrm{ppm}$. Sodium and potassium levels were measured in the presence of $2 \mathrm{mmol} \mathrm{HCl}$ and $30 \mathrm{mmol} \mathrm{CsCl}$. Calcium and magnesium were measured in the presence of $2 \mathrm{mmol}$ $\mathrm{HCl}$ and $0.6 \%$ lanthanum.

\section{Steroid hormone measurement}

Steroids were assayed in blood plasma and seminal fluid after extraction with ethylacetate:cyclohexane (50:50). The radioimmunoassay for 17,20P was performed according to Fostier and Jalabert (1986). Cross-reactivities with progestagens and other steroids were equal to or less than $2 \%$ (expressed as the ratio of the mass of $17,20 \mathrm{P}$ to the mass of steroid required to decrease bound level of the tracer to half its value without competitor). The sensitivity was $50 \mathrm{pg} / \mathrm{ml}$. The radioimmunoassay for $11-\mathrm{KT}$ was performed as described by Fostier et al. (1982). The main cross-reactivity with other androgens was under $2 \%$. The sensitivity was $50 \mathrm{pg} / \mathrm{ml}$. For both steroids, the intra-assay coefficients of variation were under $10 \%$.

\section{Data analyses}

All parameters were expressed as arithmetical means \pm 1.96 SEM or \pm standard deviation. Relationships between particular parameters were characterized using correlation coefficients and were considered to be significant at the level of $p=0.01$. Paired-sample t-test and Mann-Whitney U-test were employed to analyze differences between means, which were considered to be significant at the level of $p \leq 0.05$. 


\section{RESULTS}

\section{Changes of milt parameters during the spermiation period (experiment 1)}

During the period of study, the twin deferent ducts contained large volumes of milt. The mean total milt volume obtained from the ducts and this volume expressed per kg body weight (Fig. 1) do not vary significantly between sampling times. Individual values varied between 10 and $82 \mathrm{ml}$. Throughout the period, about as much milt was stored in the ducts as was contained in the testes (Fig. 1). The highest individual total volume of milt collected from a whole genital tract (testes plus deferent ducts) was $159 \mathrm{ml}$.

The $\mathrm{K}^{+}$concentrations (Fig. 2) in seminal fluid from each part of the duct and in blood plasma were stable, especially from Jan. 22th to March 24th. Blood plasma $\mathrm{Na}^{+}$(Fig. 2) displayed its lowest mean concentration at the beginning of February. In at least parts I and III of the deferent ducts, the mean $\mathrm{Na}^{+}$ levels were significantly higher on March 24th than 2 months earlier. While the mean $\mathrm{Cl}^{-}$concentration in blood plasma showed moderate variations (125 to $148 \mathrm{mmol}$ ) which paralleled those of plasma $\mathrm{Na}^{+}$, the mean concentration of this ion in the ducts did not show significant changes.

Mean blood plasma $\mathrm{Ca}^{2+}$ level (Fig. 3) was significantly lower in the March 24th sample than in that from January 7 th. Seminal $\mathrm{Ca}^{2+}$ levels fluctuated below the plasma level, with the exception of the last sampling time when they were maximal and not significantly different from the blood level. In parts I and III of the deferent ducts, the mean $\mathrm{Ca}^{2+}$ levels were significantly higher on March 24th than two months earlier. The $\mathrm{Mg}^{2+}$ levels (Fig. 3) in seminal fluids from the deferent ducts and in blood were not different and quite stable with the exception of the last sampling time when in parts I and II the $\mathrm{Mg}^{2+}$ levels were significantly higher than two months earlier and than in blood.

Mean blood plasma 11-KT level (Fig, 4) was maximal at the beginning of February. Plasma levels of $17,20 \mathrm{P}$ (Fig. 4) which did not vary until the end of February, increased, with large individual variations,

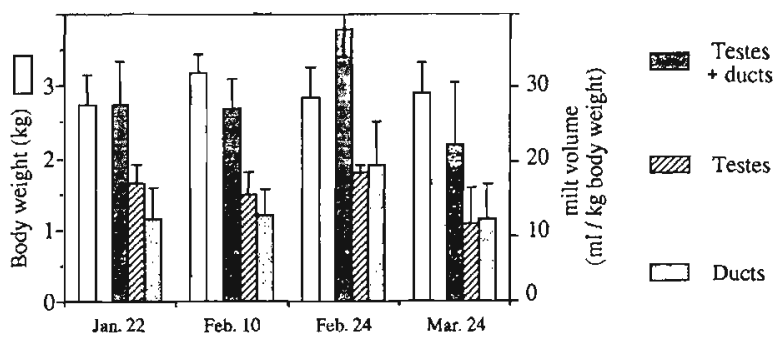

Figure 1. - Changes of the body weight and of the volume of milt collected, per $\mathrm{kg}$ body weight, from a genital tract (testes plus deferent ducts), from a pair of testis and from the deferent ducts. Mean \pm standard deviation ( $n=6$, or 4 for the last sampling time).

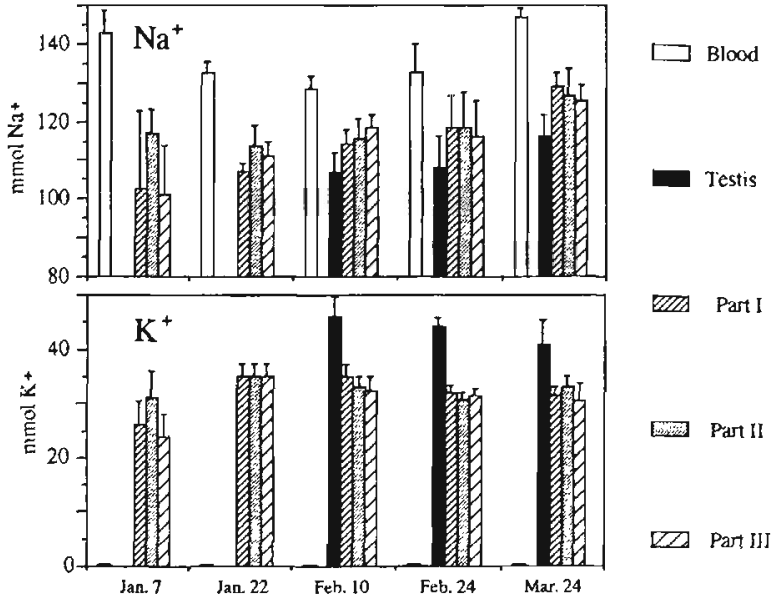

Figure 2. - Changes of the $\mathrm{Na}^{+}$and $\mathrm{K}^{+}$concentrations in blond and in the seminal fluid over the sampling period and along the genital tract. Mean \pm standard Jeviation $(n=6$, or 4 for the last sampling time). In January, no testicular fluid could he obtained. Blood $\mathrm{K}^{+}$ concentrations were around $0.3 \mathrm{mmol}$.

at the end of March. From the end of January to the end of March the ratio 17,20P:11-KT increased progressively being equal to $0.07,0.08,0.14$ and 0.44 respectively. In every part of the genital tract, the 11 KT levels (Fig. 4) were stable throughout the period of study and generally significantly lower $(p<0.01)$ than the blood levels with the exception of the testis value in March. At least in parts I and II of the deferent ducts, the 17,20P levels (Fig. 4) were higher in March than one month and a half earlier (Feb. 10th). In parts II and III of the deferent ducts, 17,20P levels were significantly lower than in blood plasma in January 22th and February 10th.

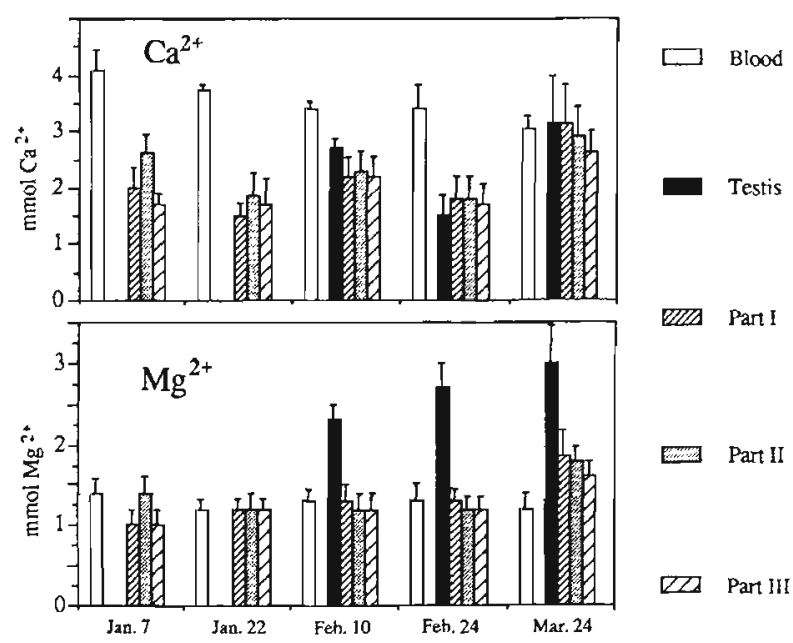

Figure 3. - Changes of the $\mathrm{Ca}^{2+}$ and $\mathrm{Mg}^{2+}$ concentrations in blood and in the seminal fluid over the sampling period and along the genital tract. Mean \pm standard deviation ( $\mathrm{n}=6$, or 4 for the last sampling time). In January, no testicular fluid could be obtained. 

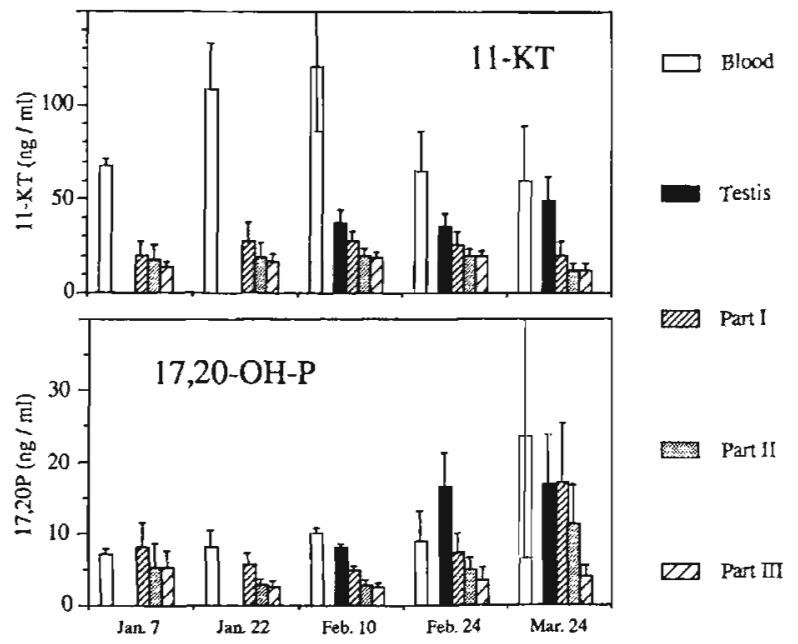

Figure 4. - Changes of 11-ketotestosterone (11-KT) and $17 \mathrm{ck}-$ hydroxy, 20/-dihydroprogesterone $(17,20 \mathrm{P})$ concentrations in blood and in the seminal fluid over the sampling period and along the genital tract. Mcan \pm standard deviation ( $\mathrm{n}=6$, or 4 for the last sampling time). In January, no testicular fluid could be obtained.

Percentages of motile testicular spermatozoa (Fig. 5) peaked at the beginning of February, i.e. at the time of highest plasma 11-KT levels, and just before the largest volume of milt could be collected from the genital tract. These percentages then decreased until the end of March. The percentages of spermatozoa from the deferent ducts motile in DIA 532 and in the 0,5 and $10 \mathrm{mmol} \mathrm{KCl}$ solutions (Fig. 5 for part III; parts I and II which displayed similar variations of the motility of sperm are not shown) did not vary significantly between January and March. During this period which corresponded to the middle of the period of spermiation, $20 \mathrm{mmol} \mathrm{K}^{+}$completely inhibited sperm cell motility.

\section{Milt parameter changes along the genital tract}

\section{Experiment 2}

Blood osmolality was equal to $298 \pm 6.7 \mathrm{mmol} / \mathrm{kg}$ $(n=9)$. Seminal fluids from testes and from the 4 parts of the deferent ducts had similar osmolality, equal to about $285 \mathrm{mmol} / \mathrm{kg}(284 \pm 3.6$ to $287 \pm 6.4)$. "Spermatocrit 1000 g" (Fig. 6) decreased progressively from the testes to the posterior part of the ducts.

Due to the occurrence of low and high steroid levels, the nine males were classified into 2 groups according to the relative concentrations of $17,20 \mathrm{P}$ and $11-\mathrm{KT}$ in blood plasma. For the $1 \mathrm{st}$ group (A; 5 males), the mean ratio $17,20 \mathrm{P}: 11-\mathrm{KT}$ was equal to $0.09(0.03$ 0.14 ) in the blood. In the 2 nd group (B; 4 males), the relative level of $17,20 \mathrm{P}$ was about four-fold higher, i.e. the mean ratio was equal to $0.38(0.29-0.70)$. Based on the data obtained by Baynes and Scott (1985) and on the steroid data presented above for experiment 1 , group B males were assumed to be more advanced

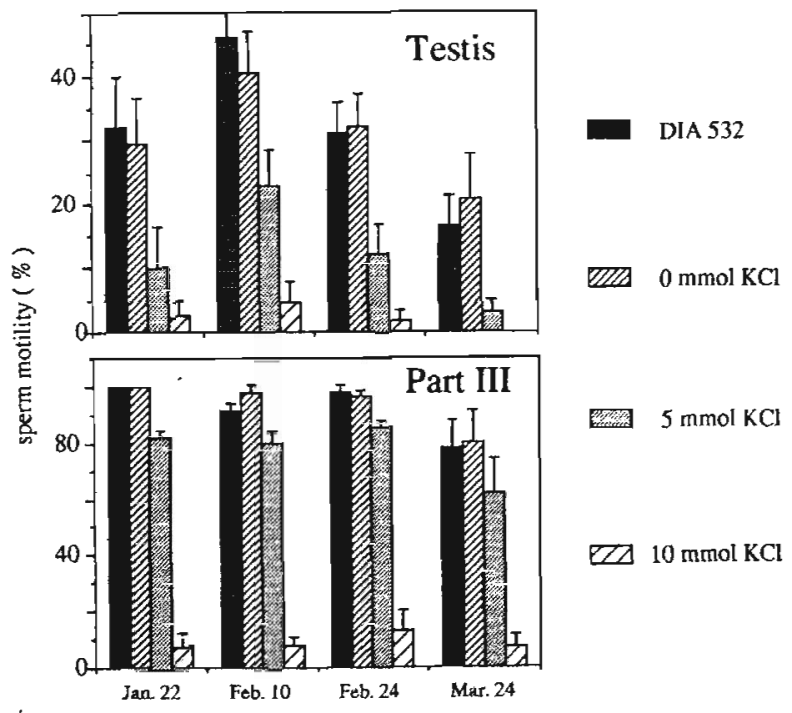

Figure 5. - Changes of the motility of sperm from testis and from the posterior part of the deferent ducts activated with diluent for artificial insemination (DIA 532) and with 0,5 and $10 \mathrm{mmol} \mathrm{KCl}$ solutions. Mean \pm standard deviation ( $n=6$, or 4 for the last sampling time).

in their individual spermiation period. This was also suggested by a higher mean milt volume obtained from the twin deferent ducts: $20.7 \mathrm{ml}(16-30)$ vs $14.7 \mathrm{ml}$ $(4-22)$.
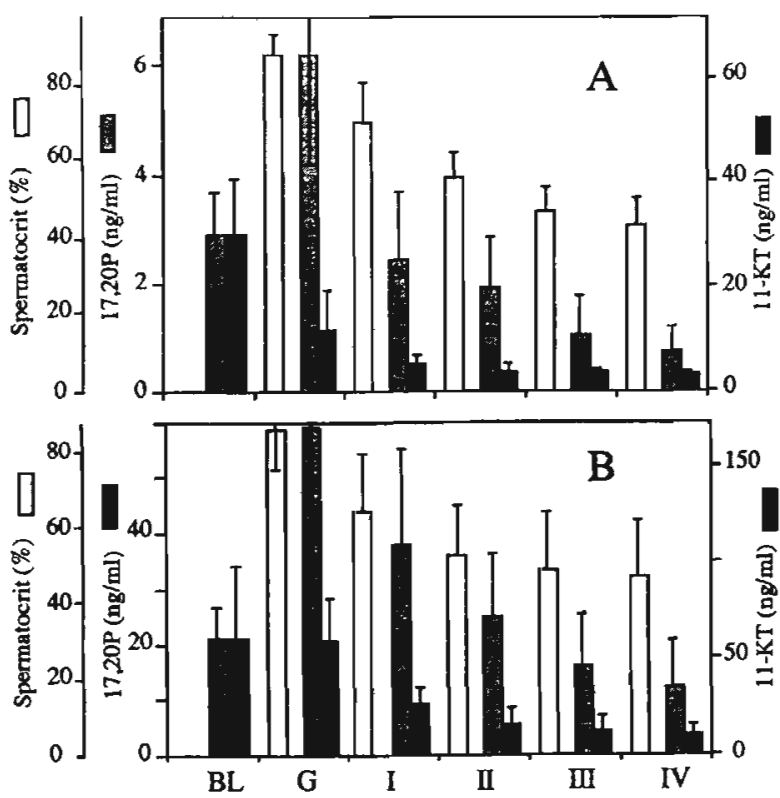

Figure 6. - Levels of 11-ketotestosterone (11-KT) and 17 $\alpha$-hydroxy, $20 \beta$-dihydroprogesterone $(17,20 \mathrm{P})$ in blood $(\mathrm{BL})$ and in seminal fluid along the genital tract (G: testis; I to IV: anterior to posterior parts of deferent ducts). Changes of spermatocrit along the genital tract. A: 5 males; B: 4 males; the mean ratio $17,20 \mathrm{P}: 11-\mathrm{KT}$ in the blood was equal to 0.09 in group $A$ and to 0.38 in group B. Mean \pm standard deviation. 
Table 1. - Gencral characteristics of blood plasma $(n=20)$ and of scminal fluid in testes $(n=12)$ and in deferent ducts $(n=20)$. Values obtained in January 22th, February and March for blood and deferents ducts, and in February and March for testes were respectively pooled. For each variable, mean $\pm 1.96 \mathrm{SLM}$ is given. Means superscribed by the same letter, in the same column, are not significantly different (paired-sample $t$-test, $p=0$. 05 ).

\begin{tabular}{|c|c|c|c|c|c|c|c|c|}
\hline & $\begin{array}{l}\text { Osmolality } \\
\mathrm{mmol} / \mathrm{kg}\end{array}$ & $\mathrm{Na}^{+}$mmol & $\mathrm{K}^{+} \mathrm{mmol}$ & $\mathrm{Ca}^{2+} \mathrm{mmol}$ & $\mathrm{Mg}^{2+} \mathrm{mmol}$ & $\mathrm{Cl}^{-}$minul & 11- $\mathrm{KT} \mathrm{ng} / \mathrm{ml}$ & 17. $20 \mathrm{P} \mathrm{ng} / \mathrm{ml}$ \\
\hline Blood & $303^{a} \pm 8.4$ & $134^{a} \pm 5.3$ & $0.3^{\mathrm{a}} \pm 0.04$ & $3.4^{a} \pm 0.26$ & $1.3^{\mathrm{a}} \pm 0.13$ & $131^{\mathrm{a}} \pm 4.8$ & $87.2^{a} \pm 27.15$ & $11.3^{\mathrm{a}} \pm 5.68$ \\
\hline $\begin{array}{l}\text { Deferent } \\
\text { part I }\end{array}$ & $299^{a} \pm 7.0$ & $116^{h} \pm 5.7$ & $34.3^{c} \pm 1.32$ & $2.1^{b} \pm 0.40$ & $1.4^{a} \pm 0.18$ & $137^{\mathrm{a}} \pm 3.5$ & $28.9^{c} \pm 12.19$ & $7.7^{c} \pm 4.84$ \\
\hline $\begin{array}{l}\text { Deferent } \\
\text { part III }\end{array}$ & $297^{a} \pm 7.5$ & $116^{b} \pm 5.7$ & $33.6^{\mathrm{c}} \pm 1.54$ & $2.00^{b} \pm 0.35$ & $1.2^{\mathrm{a}} \pm 0.13$ & $13 x^{4} \pm 4.0$ & $16.8^{\circ} \pm 6.73$ & $3.3^{c} \pm 1.36$ \\
\hline
\end{tabular}

The mean concentrations of the 2 studied steroids, in seminal fluids along the genital tract of the two groups are shown in Figure 6. The decrease already observed in experiment 1 (Fig. 4 and Table 1) was confirmed for both steroids. In addition, it appeared that along the genital tract both steroid levels decreased proportionally faster than the spermatocrit.

In group A, the mean 11-KT level in testis fluid was about half that of the corresponding blood plasma level. In group B the two values were similar. In contrast, in both groups, $17,20 \mathrm{P}$ is 2 to 3 -fold more concentrated in testis fluid than in blood plasma.

\section{Experiment I}

For each parameter, values obtained at the last four sampling times were pooled for statistical analyses of changes along the genital tract. As observed in experiment 2, mean osmolalities of blood plasma and seminal fluid from the different parts of deferent ducts and from testes did not differ significantly and varied around $300 \mathrm{mmol} / \mathrm{kg}$ (Table 1 ). As in experiment 2 and as already observed by Morisawa and Morisawa (1988), the spermatocrit decreased significantly from the testes to part III of the ducts (Table 2). Such a decrease was assumed to be due to secretion and accumulation of seminal fluid along the genital tract.

$\mathrm{Cl}^{-}$levels were identical in blood plasma and seminal fluids from deferent ducts and testes (Table 1). $\mathrm{Na}^{+}$and $\mathrm{Ca}^{2+}$ were present in blood plasma in significantly higher concentrations than in the fluids from the genital tract (Table 1). Conversely, $\mathrm{K}^{+}$ was present in low concentrations in blood plasma $(0.3 \mathrm{mM})$ while in either 100 -fold (deferent ducts) or 140-fold (testes) higher concentrations in the seminal fluids (Table 1). The $\mathrm{Mg}^{2+}$ levels were identical in blood plasma and in deferent duct fluids, but were about twice as high in testes fluid.

High individual variations were observed in the steroid levels medsured in blood plasma and seminal fluids. However, 11-KT mean concentrations were twice as high in blood plasma as in testicular seminal fluid, but decreased regularly between testis and the posterior part of the deferent duct. A similar decrease was also observed along the genital tract for $17,20 \mathrm{P}$, but, in contrast to 11-KT, the testicular $17,20 \mathrm{P}$ level was higher than the plasma level. In the seminal fluid, $17,20 \mathrm{P}$ level was positively correlated to $\mathrm{Mg}^{2+}$ level $(p<0.001)$ and to the spermatocrit $(p<0.01)$ when the localization along the deferent duct was not taken into consideration (values from parts I to III were pooled). However, because these two correlations were not significant in each part of the duct, this suggests that $17,20 \mathrm{P}$ levels may not be functionally related $10 \mathrm{Mg}^{2+}$ level and to the spermatocrit.

The values measured in each of the 3 parts of the ducts for osmolality, $\mathrm{Na}^{+}, \mathrm{Cl}^{-}, 11-\mathrm{KT}$ and 17,20P were positively correlated $(p<0.001)$ with the respective blood plasma values. There was no such correlation

Table 2. - Spermatocrit and motility parameters of sperm from testes $(n=12$ ) and from the different parts of deferent ducts ( $\mathrm{n}=20$ ). Spermatosoa were activated either with diluent for artificial insemination (DIA 532) or with solutions containing different $\mathrm{KCl}$ concentrations. Values obtained in February and March for testes, and on January $22 n d$, February and March for deferent ducts were respectivcly pooled. For each variable mean \pm 1. 96 SEM is given. Means superscribed by the same letter, in the same column, are not significantly different (paired-sample $t$-test, $p=0$. 05).

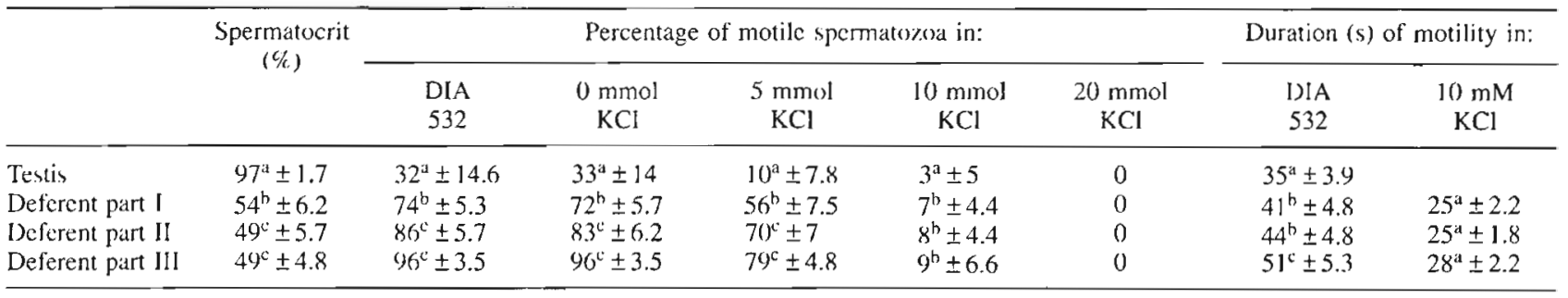


for $\mathrm{K}^{+}, \mathrm{Ca}^{2+}$ and $\mathrm{Mg}^{2+}$. This suggests that the concentrations of these latter ions in the seminal fluid are probably regulated independently of their blond levels. In each of the three parts, 1) the $\mathrm{Na}^{+}$concentration was positively correlated to $\mathrm{Mg}^{2+}$ and $\mathrm{Ca}^{2+}$ concentrations $(p<0.01)$, while it was not in blood, 2) $\mathrm{Ca}^{2+}$ and $\mathrm{Mg}^{2+}$ concentrations were positively correlated $(p<0.01)$, and they were also in blood, 3) the spermatocrit was positively correlated to the $\mathrm{Mg}^{2+}$ concentration $(p<0.01)$. This last correlation may suggest that the damaging of spermatozoa may have contributed to the increase in the seminal $\mathrm{Mg}^{2+}$ level.

When sperm motility was tested (Table 2) in DIA or in " $0 \mathrm{mmol} \mathrm{KCl"} \mathrm{solution,} \mathrm{about} \mathrm{one} \mathrm{third} \mathrm{of}$ the testicular spermatozoa were motile. Percentage of motile sperm cells in DIA 532 and in " 0 mmol KCl" solution and the duration of motility increased from testes to part III of the ducts. In all parts of the genital tract, as little as $5 \mathrm{mmol} \mathrm{KCl}$ significantly decreased the percentage of motile sperm cells and $20 \mathrm{mmol}$ $\mathrm{KCl}$ completely inhibited sperm motility everywhere. Sensitivity of motility to inhibition by $10 \mathrm{mmol} \mathrm{KCl}$ did not differ along the genital tract. Indeed, in each part about $10 \%$ of the sperm motile in DIA 532 were still motile in $10 \mathrm{mmol} \mathrm{KCl}$ and duration of motility was also reduced in similar proportion.

While the percentage of motile spermatozoa and the duration of motility in DIA increased along the deferent ducts, spermatocrit and 17,20P level declined. Observed negative correlations between the percentage of motile cells and 17,20P level in duct seminal fluid $(p)<0.001)$ or spermatocrit values $(p<0.01)$, probably reflect independent changes.

No correlation was found between parameters of sperm motility as estimated in this study and the ionic components, the osmolality or the 11-KT level of the seminal fluid.

\section{DISCUSSION}

\section{Changes of milt parameters during the spermiation period}

The concentrations of monovalent ions in seminal fluid from each part of the ducts either were stable $\left(\mathrm{K}^{+}\right.$, $\mathrm{Cl}^{-}$) or increased in March $\left(\mathrm{Na}^{+}\right)$. Munkittrick and Moccia (1987) had observed that the concentration of monovalent ions in seminal fluid of trout semen declined as the spermiation season progressed, while Piironen (1985) observed an inverse change in semen of landlocked salmon. In both studies, semen was obtained by hand-stripping and the changes the authors observed for osmolality and ion changes may be due to varying amounts of urine contamination (Rana, 1995).

The observed changes of 11-KT and 17,20P levels in blood plasma are in agreement with data obtained in rainbow trout by Baynes and Scott (1985) and in amago salmon by Sakai et al. (1989b) who have observed that plasma levels of testosterone and 11-KT peak before 17,20P peaks. In addition, Baynes and Scott (1985) have concluded 1) that periods of maximum plasma $17,20 \mathrm{P}$ concentrations correspond to those of maximum milt production (milt obtained by hand-stripping) and 2) that there could be a positive correlation between blood plasma 17,20P levels and the ratio of $\mathrm{K}^{+}: \mathrm{Na}^{+}$in seminal fluid (idem). In our study, 1) the mean volume of milt stored in deferent ducts was maximal one month (Feb. 24th) before maximum blood plasma $17,20 \mathrm{P}$ levels, and 2) the mean ratio $\mathrm{K}^{+}: \mathrm{Na}^{+}$in the various seminal fluids was maximal $(0.28-0.32$ vs $0.25-0.27)$ when blood plasma 11-KT concentrations were high (Jan. 22th and Feb. 10th). However, the studies are hardly comparable because 1) the strains were different, 2) in our study the same fish were not sampled over the period, 3 ) the methods used to estimate milt production differed and 4) the method we used to collected milt avoided contamination by urine.

\section{Milt parameter changes along the genital tract}

The 17,20P and 11-KT levels decreased along the genital tract, proportionally faster than the spermatocrit. This suggests that the decrease in sex steroid concentrations is not only due to dilution by secretion of seminal fluid, but results also from additional unknown events such as re-absorption, degradation, binding and metabolization of steroids by sperm cells and/or cells of the ducts. Whereas the level of $11-\mathrm{KT}$ in testis fluid either was similar to that in blood plasma or lower, the level of $17,20 \mathrm{P}$ was higher in testis fluid than in plasma. Androgens are secreted by Leydig cells (Loir, 1990), i.e. by cells located outside the germinal compartment. Conversely, although it cannot be excluded that $17,20 \mathrm{P}$ is also produced in small amounts by interstitial cells (Loir, 1990) this progestagen is mainly produced in the germinal compartment by spermatozoa (Sakai et al., 1989a) and spermatogenic cells (Vizziano et al., 1995) which convert $17 \alpha$-hydroxyprogesterone. This difference in origin of androgens and 17,20P probably explains that testicular levels of 17,20P are higher than the plasma levels while it is the inverse situation for 11-KT.

Mean osmolalities of blood plasma and seminal fluid were around $300 \mathrm{mmol} / \mathrm{kg}$. Isotonicity of both fluids in the trout has been observed when milt was obtained directly from the deferent duct, either by opening the abdomen (Morisawa et al, , 1983) or by catheterization (Rana, 1995). In contrast, when milt was collected by hand-stripping, lower osmolality values were obtained for seminal fluid, due to $5-80 \%$ dilution by urine, even when care was taken to avoid such contamination (Piironen, 1985; Munkittrick and Moccia, 1987; Malejac et al., 1990; Rana, 1995).

Most of the values we obtained for the ion levels were close to those previously found (Morisawa, 1985; 
Baynes and Scott, 1985; Marshall, 1986), except for the blood plasma $\mathrm{K}^{+}$level that was ten-fold lower than that found by Morisawa (1985), possibly reflecting the low $\mathrm{K}^{+}$level present in the water at the fish farm. $\mathrm{K}^{+}$and $\mathrm{Mg}^{2+}$ levels significantly higher in the testes fluid than in the deferent duct fluids may result from the damaging of the spermatozoa and the release of intracellular ions during the extraction of this particular fluid. Similar artefacts have been observed in seminal fluid ion concentrations after damaging of spermatozoa by freeze-thawing (Schmehl et al,, 1987).

Motility of sperm from testis and from deferent ducts was completely inhibited with $20 \mathrm{mmol} \mathrm{K}$. Billard and Cosson (1992) observed the same inhibiting effect on ejaculated sperm with $40 \mathrm{mmol}$ $\mathrm{K}^{+}$, with the exception of the beginning and the end of the period of spermiation, as spermatozoa were motile even in the presence of $80 \mathrm{mmol} \mathrm{K}^{+}$. One third of the testicular spermatozoa were motile in DIA 532. When Billard and Cosson (1992) assayed motility of sperm from trout testes just at the end of spermatogenesis, they observed that $10 \%$ of sperm cells were motile. Miura et al. (1992) have reported that, in masu salmon, sperm from spermiating testes are immotile. This could reflect species differences but more probably this reflects differences in the dilution media used for those assays.

No correlation was found between the studied parameters of sperm motility and the studied physicochemical parameters of the seminal fluid. However, motility parameters such as flagellar beat frequency or trajectory shape (Billard and Cosson, 1992) were not measured and an effect on these parameters cannot be excluded. In the present state of our knowledge, no ionic constituent of the seminal fluid, with the exception of proton ( $\mathrm{pH}$; Morisawa and Morisawa, 1990; Miura et al., 1992) and bicarbonate concentration (Morisawa and Morisawa, 1990) seems to influence the acquisition of sperm motility, the percentage of motile spermatozoa and the duration of movement in trout. Sperm motility is supported by intracellular ATP resulting from glycolysis and catabolism of triglycerides (Lahnsteiner et al., 1993). Benau and Terner (1980) observed that the intracellular content of ATP decreases during the breeding season and that the shortest duration of motility was when level of ATP was low. This suggests that investigation of the changes of energy metabolites in spermatozoa and seminal fluid during the spermiation period would probably provide information about the semen components which could influence sperm motility.

\section{CONCLUSION}

Our results confirm that the ionic and steroidal composition of the seminal fluid differs conspicuously from that of the blood plasma and that active processes of secretion and reabsorption are probably involved in its regulation. For some parameters (osmolality, $\mathrm{Na}^{+}$, $\left.\mathrm{Cl}^{-}, 1\right]-\mathrm{KT}, 17,20 \mathrm{P}$ ), the values in seminal fluid were correlated with those in blood plasma, while they were not for others $\left(\mathrm{K}^{+}, \mathrm{Ca}^{2+}, \mathrm{Mg}^{2+}\right)$; this suggests that diverse mechanisms control the composition of the seminal fluid. Finally, no seminal fluid parameter was identified to which sperm cell motility would be functionally related. Further studies of possible relationships between the major parameters of sperm movement (beat frequency, sperm velocity, diameter of sperm trajectories; Billard and Cosson, 1992) and inorganic and organic constituents of seminal fluid and spermatozoa are needed to identify which constituents influence sperm motility, i.e. sperm quality from the point of view of artificial salmonid fertilization.

\section{Acknowledgments}

This work was financially supported by the Institut National de la Recherche Agronomique. The authors are grateful to the staff of the INRA fish hatchery for help and cooperation.

\section{REFERENCES}

Baynes S. M., A. P. Scott 1985. Seasonal variations in parameters of milt production and in plasma concentration of sex steroids of male rainbow trout (Salmo gairdneri). Gen. Comp. Endocrinol. 57, 150-160.

Benau D., C. Temer 1980. Initiation, prolongation, and reactivation of the motility of salmonid spermatozoa. Gamete Res. 3, 247-257.

Billard R. 1975. L'insémination artificielle de la truite Salmo gairdneri Richardson. IV Effets des ions $\mathrm{K}^{+}$et $\mathrm{Na}^{+}$sur la conservation du pouvoir fécondant des gamètes. Bull. Fr. Piscic. 256, 88-98.
Billard R. 1976. Variation de la qualité des gamètes à différents niveaux du tractus génital chez la truite arcen-ciel. Ann. Hydrobiol. 7, 97-104.

Billard R. 1977. Utilisation d'un système tris-glycocolle pour tamponner le dilueur d'insémination pour truite. Bull Fr. Piscic. 264, 102-112.

Billard R., M. P. Cosson 1992. Some problems related to the assessment of sperm motility in freshwater fish. J. Exp. Zool. 261, 122-131.

Blackmore P. F., S. J. Beebe, D. R. Danforth, N. Alexander 1990. Progesterone and 17 $\alpha$-hydroxyprogesterone novel stimulators of calcium influx in human sperm. J. Biol. Chem. 265, 1376-1380. 
Fostier A., B. Jalabert 1986. Steroidogenesis in rainbow trout (Salmo gairdneri) at various preovulatory stages: Changes in plasma hormone levels and in vivo and in vitro responses of the ovary to salmon gonadotropin. Fish Physiol. Biochem. 2, 87-99.

Fostier A., R. Billard, M. Legendre, S. Marlot 1982. Plasma 11-oxotestosterone and gonadotropin during the beginning of spermiation in rainbow trout (Salmo gairdneri). Gen. Comp. Endocrinol. 46, 428-434.

Lahnsteiner F., R. A. Patzner, T. Weismann 1992. The spermatic ducts of salmonid fishes (Salmonidae, Teleostei). Morphology, histochemistry and composition of the secretion. J. Fish Biol. 42, 79-93.

Lahnsteiner F., R. A. Patzner, T. Weismann 1993. Energy resources of spermatozoa of the rainbow trout Oncorhynchus mykiss (Pisces, Teleostei). Reprod. Nutr. Dev. 33, 349-360.

Loir M, 1990. Trout steroidogenic testicular cells in primary culture II. Stcroidogenic activity of interstitial cells, Sertoli cells, and spermatozod. Gen. Comp. Endocrinol. 78, 388-398.

Loir M., C. Labbè, D. Vizziano 1990. Steroids in seminal fluid in the rainbow trout. Gen. Comp. Endocrinol. 82, 241.

Maisse G., A. Pinson, M. Loir 1988. Caractérisation de l'aptitude à la congélation du sperme de truite arc-enciel (Salmo gairdneri) par des critères physico-chimiques. Aquat. Living Resour. 1, 45-51.

Maisse G., R. Billard, F. André, J. Cosson, F. Le Gac 1990. Amélioration de la motilité des spermatozoïdes testiculaires de néornâles de truite commune (Salmo trutta) au début de la période de reproduction. Aquat. Living Resour. 8, 191-194.

Malejac M. L., M. Loir, G. Maisse 1990. Qualité de la membrane des spermatozoïdes de truite arc-en-ciel (Oncorhynchus mykiss); relation avec l'aptitude du sperme à la congélation. Aquat. Living Resour. 3, 43-54.

Marshall W. S., S. E. Bryson 1988. Evidence for $\mathrm{Cl}^{\text {- }}$ dependent $\mathrm{K}^{+}$secretion by the blood-testis barrier of brook trout. Can. J. Zool. 66, 1603-1609.

Marshall W. S., S. E. Bryson, D. R. Idler 1989. Gonadotropin stimulation of $\mathrm{K}^{+}$secretion and $\mathrm{Na}^{+}$ absorption by brook trout (Salvelinus fontinalis) sperm duct epithelium. Gen. Comp. Endocrinol. 75, 118-128.

Meizel S., K. O. Turner 1991. Progesterone acts at the plasma membrane of human sperm. Mol. Cell. Endocrinol. 11, R1-R5.
Miurd T., K. Yamauchi, H. Takahashi, Y. Nagahama 1992. The role of hormones in the acquisition of sperm motility. J. Exp. Zool. 261, 359-363.

Morisawa M. 1985. Initiation mechanism of sperm motility at spawning in teleosts. Zool. Sci. 2, 605-615.

Morisawa S., M. Morisawa 1986. Acquisition of potential for sperm motility in rainbow trout and chum salmon. J. Exp. Biol. 126, 89-96.

Morisawa S., M. Morisawa 1988. Induction of potential for sperm motility by bicarbonate and $\mathrm{pH}$ in rainbow trout and chum salmon. J. Exp. Biol. 136, 13-22.

Morisawa M., K. Suzuki, S. Morisawa 1983. Effects of potassium and osmolality on spermatozoan motility of salmonid fishes. J. Exp. Biol. 107, 105-113.

Morisawa S., K. Ishida, M. Okuno, M. Morisawa 1993. Roles of $\mathrm{pH}$ and cyclic adenosine monophosphate in the acquisition of potential for sperm motility during migration from the sea to the river in chum salmon. Mol. Reprod. Dev. 34, 420-426.

Munkittrick K. R., R. D. Moccia 1987. Seasonal changes in the quality of rainbow trout (Salmo gairdneri) semen: effect of a delay in stripping on spermatocrit, motility, volume and seminal plasma constituents. Aquaculture 64, 147-156.

Piironen J. 1985. Variation in the properties of milt from the finnish landlocked salmon (Salmo salar M. sebago Girard) during a spawning season. Aquaculture 48, 337-350.

Rana K. J. 1995. Preservation of gametes. In: Broodstock management and cgg and larvae quality. N. Bromage, R. J. Roberts eds. Blackwell Science, Oxford, 53-75.

Sakai N., H. Ueda, N. Suzuki, Y. Nagahama 1989a. Involvement of sperm in the production of $17 \alpha, 20 \beta$ dihydroxy-4-pregnen-3-one in the testis of spermiating rainbow trout, Salmo gairdneri. Biomed. Res. 10, 131-138.

Sakai N., H. Ueda, N. Suzuki, Y. Nagahama 1989b. Steroid production by amago salmon (Oncorhynchus rhodurus) testes at different developmental stages. Gen. Comp. Endocrinol. 75, 231-240.

Schmehl M. K., E. F. Graham, D. A. Erdahl 1987. Chemical constituents of trout seminal plasma after minimal cell damage treatments with possible applications to semen evaluation assays. Aquaculture 62, 311-318.

Vizziano D., A. Fostier, F. Le Gac, M. Loir 1996. 20ßhydroxysteroid dehydrogenase activity in nonflagellated germ cells of rainbow trout testis. Biol. Reprod. 54, 1-7. 